Jurnal Keperawatan Silampari

Volume 5, Nomor 1, Desember 2021

e-ISSN: 2581-1975

p-ISSN: 2597-7482

DOI: https://doi.org/10.31539/jks.v5i1.2667

\title{
DAMPAK GAWAI TERHADAP PERKEMBANGAN ANAK USIA PRASEKOLAH PADA MASA PANDEMI COVID-19
}

\author{
Andra Saferi Wijaya ${ }^{1}$, Nehru Nugroho ${ }^{2}$ \\ Politeknik Kesehatan Kementerian Kesehatan Bengkulu ${ }^{1,2}$ \\ andrasw88@gmail.com ${ }^{1}$
}

\begin{abstract}
ABSTRAK
Penelitian ini bertujuan mengekplorasi persepsi orang tua tentang dampak gawai terhadap perkembangan anak usai prasekolah di PAUD IT Baitul Izzah Kota Bengkulu. Metode penelitian yang dilakukan kualitatif dengan pendekatan fenomenologi. Hasil Penelitian di dapatkan 6 tema yang saling berkaitan tentang dampak gawai terhadap perkembangan anak.Tema pertama makna bagi orang tua tentang pemberian gawai pada anak, tema kedua menunjukan konten yang dibuka oleh anak pada gawai, tema ketiga durasi penggunaan gawai pada naka usia 4-6 tahun, tema ke empat kontrol terhadap penggunaan gawai pada anak dan tema ke lima dampak gawai pada perkembangan anak. Simpulan, penggunaan gawai pada anak memiliki dampak positif dan negatif pada perkembangan anak.
\end{abstract}

Kata Kunci: Covid-19, Gawai, Orang Tua, Pandemi, Perkembangan

\section{ABSTRACT}

This study explores parents' perceptions of the impact of gadgets on children's development after preschool at PAUD IT Baitul Izzah Bengkulu City. The research method is qualitative with a phenomenological approach. The results of the study found six interrelated themes about the impact of gadgets on children's development. The first theme is meaning for parents about giving gadgets to children; the second theme shows the content opened by children on gadgets. The third theme is the duration of using gadgets for children aged 4-6. years, the fourth theme is control over the use of devices in children, and the fifth theme is the impact of machines on child development. In conclusion, the use of gadgets in children has a positive and negative effect on child development.

Keywords: Covid-19, Device, Parents, Pandemic, Development

\section{PENDAHULUAN}

Semakin hari teknologi berkembang dengan sangat pesat sesuai dengan perkembangan zaman. Perkembangan teknologi yang begitu cepat tentu dapat merubah pola pikir manusia menjadi serba instan. Perkembangan teknologi ini sangat membantu pekerjaan manusia. Salah satu bentuk teknologi yang banyak beredar di masyarakat saat ini adalah gawai (Rusmianto \& Putra, 2020).

Peningkatan penggunaan gawai internet di seluruh dunia terutama di Indonesia dapat dilihat dari hasil survei APJII (Asosiasi Penyelenggara Jasa Internet Indonesia) pada tahun 2020 mencapai 196,7 Juta dari total 256,2 juta penduduk Indonesia. Sedangkan di Provinsi Bengkulu penggunaan gawai mencapai 1,5 Juta jiwa. Hal ini sesuai dengan data dari Kominfo yang menyatakan 10 persen penggua internet di Indonesia adalah anak-anak di 
bawah usia 15 tahun. Penggunaan internet sebagian besar perangkat yang paling sering digunakan untuk mengakses internet ialah handphone sebanyak 47,6\%, mengakses internet menggunakan komputer $1,7 \%$ dan $50,7 \%$ menggunakan perangkat handphone dan komputer.

Data tersebut memperlihatkan bahwa penggunaan internet di Indonesia mengalami kenaikan yang sangat signifikan hanya dalam kurun waktu 2 tahun. Hal ini juga di dukung saat ini pandemic Covid-19 sangat mempengaruhi peningkatan penggunaan gawai pada anak, terumata terkait kegiatan pembelajaran. Selain itu gawai memiliki manfaat yang banyak dengan harga yang relatif murah. Maraknya penggunaan gawai saat ini membuat banyak sekali persepsi mengenai gawai, persepsi ini ada yang merupakan persepsi yang negatif ataupun persepsi yang positif.

Banyaknya konten yang dapat dilihat oleh anak tentu akan memberikan dampak yang akan diterima, baik itu dampak positif atau dampak negatif dari penggunaan gawai bergantung dengan kontrol yang dilakukan oleh orang tua kepada anak ketika anak sedang menggunakan gawai. Biasanya orang tua yang terlalu sibuk dengan pekerjaannya tentu akan memberikan gawainya kepada anaknya supaya anak dapat bermain sendiri dengan tenang. Pendapat ini sejalan dengan penelitian yang dilakukan oleh (Rusmianto \& Putra, 2020)yang menyatakan bahwa $74 \%$ orang tua mengemukakan bahwa gawai dapat menjadi pengasuh kedua, karena dengan menggunakan gawai anak akan duduk dan sibuk memainkan gawainya sehingga orang tua bisa melakukan aktivitas tanpa terganggu. Selain itu, ada juga orang tua yang tidak memberikan izin kepada anaknya untuk menggunakan gawai.

Bedasarkan studi pendahuluan yang dilakukan peneliti pada anak PAUD IT Baitul Izzah Kota Bengkulu didapatkan data sebagian besar anak sudah menggunakan gawai baik untuk pembelajaran, maupun sebagai sarana komunikasi dengan orang tua. Hal ini disampaikan oleh salah seorang guru di PAUD IT Baitul Izzah Kota Bengkulu. Hasil wawancara dengan salah seorang orang tua juga menyampaikan anak mereka kebanyakan menghabiskan waktu mereka untuk bermain gawai, sehingga dari segi perkembangan motorik dan sosialisasi dapat berpengaruh.

Penggunaan gadget yang berlebihan pada anak akan berdampak negatif karena dapat menurunkan daya konsentrasi dan meningkatkan ketergantungan anak untuk dapat mengerjakan berbagai hal yang semestinya dapat mereka lakukan sendiri. Dampak lainnya adalah semakin terbukanya akses internet dalam gadget yang menampilkan segala hal yang semestinya belum waktunya dilihat oleh anak-anak (Maria \& Novianti, 2020; Chusna, 2017).

Penggunaan gadget pada anak usia prasekolah, menurut penelitian Setianigsih (2018) berdampak pada resiko gangguan pemusatan perhatian dan hiperaktivitas. Penelitian lain juga menunjukkan terdapat dampak negatif adiksi penggunaan smartphone terhadap aspek-aspek akademik (Utami, 2019). Perilaku kecanduan gadget pada siswa juga pernah diteliti oleh Wardhani (2018) yang meneliti tentang perspektif rasa hormat pada siswa SMP. Namun penelitian ini berfokus pada dampak gawai terhadap perkembangan anak usia prasekolah pada masa pandemi covid-19.

\section{METODE PENELITIAN}

Rancangan penelitian menggunakan desain penelitian kualitatif dengan pendekatan fenomenologi. Pemilihan metode fenomenologi berdasarkan beberapa pertimbangan yaitu bahwa dengan metode fenomenologi memungkinkan untuk melakukan eksplorasi mendalam makna fenomena pengalaman, dalam hal ini persepsi dan perilaku empati secara 
lebih mendalam terkait pengaruh gawai terhadap perkembangan anak.

Penelitian ini dilakukan di PAUD IT Baitul Izzah Kota Bengkulu pada bulan September-Desember 2020. Pemilihan lokasi penelitian ini berdasarkan pada pertimbangan bahwa PAUD IT Baitul Izzah Kota Bengkulu merupakan sekolah usia dini dengan jumlah partisipan yang beragam guna memenuhi jumlah paritisipan yang heterogen.

Partisipan berasal dari kelompok orang tua dan kelompok guru PAUD dengan kriteria inklusi pada kelompok orang tua dalam penelitian ini adalah (1). Orang tua yang bersedia menjadi partisipan dalam penelitian dengan menandatangani informed consent; (2). Orang tua yang mengantar dan menjemput anaknya kesekolah; (3). Orang tua mampu berkomunikasi dalam bahasa Indonesia; Kriteria ekslusi adalah orang tua dengan anak tidak diantar oleh orang tuanya. Sedangkan kriteria inklusi untuk partisipan dari kelompok guru yaitu: (1). Pendidikan terakhir minimal D3; (2). Guru yang bertugas di PAUD IT Baitul Izzah Kota Bengkulu lebih dari 1 tahun, (3). Bersedia menjadi partisipan dengan mengisi lembar informed consent. Sedangkan kriteri ekslusi adalah guru yang sedang magang atau cuti selama periode penelitian dilakukan.

Jumlah sampel yang menjadi partisipan pada penelitian ini berjumlah 15 orang yang terdiri dari 10 orang tua pasien dan 5 guru sebagai partisipan triangulasi. Saat mencapai partisipan ke-9 dari orang tua data yang terkumpul telah mencapai titik saturasi, yaitu data diperoleh telah lengkap, komprehensif dan jenuh, begitupun data dari kelompok guru yang di lakukan FGD.

Instrumen utama dalam penelitian ini adalah peneliti sendiri karena hanya manusia yang mampu berhubungan dengan responden dalam memperoleh data secara mendalam. Kisi-kisi instrumen digunakan untuk mempermudah peneliti dalam hal membuat pedoman wawancara untuk memperoleh data yang diperlukan.

Pengumpulan data dalam penelitian ini menggunakan teknik wawancara mendalam (In-depth Interview) dan langsung bertatap muka dengan partisipan di Sekolah PAUD. Alat bantu yang akan digunakan dalam penelitian ini berupa alat perekam digital merek Sony ICD-PX4440 yang memiliki kualitas perekaman yang baik dan membantu merekam informasi dari hasil wawancara dengan partisipan. Lembar observasi juga digunakan untuk mencatat hasil observasi partisipan dalam penelitian ini. Penyimpanan data berupa transkrip rekaman audio, membuat copy dan back up dalam file komputer.

Pengumpulan data dilakukan setelah mendapatkan surat kelayakan etik (ethical clearance), dari Komite Etik Penelitian Poltekkes Kemenkes Bengkulu. Proses pengumpulan data diawalai dengan peneliti menyiapkan alat perekam berupa digital recorder dan alat tulis sebelum melakukan wawancara. Proses pengambilan data menggunakan panduan wawancara yang berisi pertanyaan terbuka. Peneliti tidak mengarahkan jawaban partisipan maupun memberikan penilaian berdasarkan pemahaman atau pengalaman yang dimiliki oleh peneliti sebelumnya. Bahasa yang mudah dipahami yang digunakan oleh peneliti dalam melakukan wawancara dan klarifikasi terhadap jawaban yang kurang jelas.

Proses analisis data penelitian kualitatif ini dilakukan secara bersamaan dengan pengumpulan data hasil wawancara, observasi dan catatan lapangan. Peneliti melakukan analisis data dengan cara, setiap selesai wawancara peneliti langsung membuat transkrip hasil wawancara yang dilengkapi dengan catatan lapangan, dan selanjutnya transkrip tersebut dibaca berulangkali. Analisis data dilakukan secara manual berdasarkan analisis isi (content analysis) menurut tahap analisis Colaizzi. Peneliti juga akan dibantu dengan Software OpenCode versi 4.0.2.3, yaitu sebuah Software gratis yang dikembangkan oleh ITS and Division of Epidemiology University of Umea, Department of Public Health and 
Clinical Medicine (2011) di Umea University Swedia. Lisensi software ini diberikan secara gratis dan dapat di download di //http.software.infomer.com. Penggunaan Software ini akan memberikan kemudahan dalam analisis data yaitu pada saat menentukan kata kunci, kategori dan sub tema. Software OpenCode versi 4.0.2.3 akan membantu peneliti dalam menyimpan kata kunci dan kategori sehingga memudahkan peneliti saat menulis quotasi.

Uji keabsahan data dilakukan dengan uji kredibilitas dalam penelitian ini dilakukan dengan triangulasi dan member checking. Triangulasi yang dilakukan yaitu triangulasi sumber dan triangulasi metode. Peneliti mengecek data yang telah didapatkan saat wawancara dalam bentuk transkrip verbatim, dan menyesuaikan dengan catatan lapangan.Member checking juga peneliti lakukan, yaitu memeriksa hasil wawancara dengan partisipan untuk memastikan kesesuaian data yang diperoleh merupakan data yang sebenarnya dari partisipan.

Teknik yang digunakan dalam memperoleh dependability dengan proses telaah data dan dokumen yang diperoleh dan mendukung secara menyeluruh peneliti lain sehingga memungkinkan peneliti lain mempelajari dan memberikan pertanyaan serta menganalisa kembali hasil penelitian. Konfirmabilitas penelitian ini diperoleh dengan cara menunjukan seluruh transkrip dan catatan lapangan kepada tim peneliti, kemudian berdiskusi bersama untuk menentukan tema dari hasil penelitian yang disusun dalam bentuk skema tema. Uji confirmability dilakukan bersamaan dengan dependability. Prinsip transferbilitas pada penelitian ini dilakukan dengan cara peneliti menulis laporan penelitian yang diuraikan dengan jelas, rinci, sistematis dan mudah dimengerti oleh pembaca sehingga pembaca dapat memperoleh gambaran yang jelas tentang persepsi orang tua tentang dampak gawai terhadap perkembangan anak. Pembahasan tema penilitian ini dilakukan dengan menggunakan jurnal dan hasil-hasil penelitian yang telah terpublikasi dan berkaitan dengan fenomena yang diteliti.

\section{HASIL PENELITIAN Partisipan Orang tua}

Tabel. 1

Karakteristik Partisipan Orang tua

\begin{tabular}{llccccccccc}
\hline Partisipan & R1 & R2 & R3 & R4 & R5 & R6 & R7 & R8 & R9 & R10 \\
\hline Usia & 35 & 45 & 31 & 28 & 36 & 36 & 40 & 32 & 37 & 33 \\
\hline $\begin{array}{l}\text { Pendidikan } \\
\text { Terakhir }\end{array}$ & S1 & S1 & S1 & S1 & SMA & SMA & SMA & D1 & SPK & SD \\
\hline Pekerjaan & PNS & PNS & PNS & Swasta & IRT & Swasta & IRT & Swasta & PNS & IRT \\
\hline $\begin{array}{l}\text { Jumlah } \\
\text { anak yang } \\
\text { diasuh } \\
\text { termasuk } \\
\text { anak yang } \\
\text { dirawat) }\end{array}$ & 2 & 3 & 1 & 1 & 2 & 2 & 3 & 1 & 3 & 1 \\
\hline
\end{tabular}

Berdasarkan tabel 2 menunjukkan bahwa sebagian besar partisipan orang tua adalah ibu berkerja sebagai pegawai negeri dan pegawai swasta, dengan proporsi latar belakang pendidikan partisipan orang tua bervariais yaitu 5 Orang berpendidikan tinggi (D1-S1), 4 Orang berpendidikkan menengah SMA sederajat dan satu orang partisipan berpendidikan rendah yaitu SD. Usia orang tua berada pada rentang 28 hingga 45 tahun. 


\section{Partisipan Guru PAUD}

Tabel. 2

Karakteristik Partisipan Guru

\begin{tabular}{|c|c|c|c|c|c|}
\hline $\begin{array}{l}\text { Partisipan } \\
\text { Keterangan }\end{array}$ & $\mathrm{R} 11$ & R12 & $\mathrm{R} 13$ & R14 & R15 \\
\hline Usia & 28 tahun & 45 tahun & 38 tahun & 43 tahun & 47 tahun \\
\hline Pekerjaan & Guru & Guru & Guru & Guru & Guru \\
\hline Pendidikan Terakhir & S1 & S1 & S1 & S1 & S1 \\
\hline Lama pengalaman mengajar & 5 tahun & 15 tahun & 14 tahun & 15 tahun & 18 tahun \\
\hline
\end{tabular}

\section{Hasil Analisis Tematik}

Analisis pada penelitian ini menerapkan langkah analisis menurut Colaizzi dalam mengembangkan tema. Pada proses analisis peneliti dibantu oleh Software OpenCode versi 4.0.2.3. Berdasarkan hasil analisis tersebut, tema-tema yang muncul antara lain: 1) Makna bagi orang tua tentang pemberian gawai pada anak; 2). Konten yang dibuka anak; 3). Durasi penggunan internet; 4). Kotrol orang tua dalam pemberian gawai pada anak; 5) Dampak Positif dan Negatif.

\section{Makna bagi Orang tua tentang Pemberian Gawai pada Anak}

Tabel. 3

Analisis Tematik untuk Tema Makna bagi Orang tua tentang Pemberian Gawai pada Anak

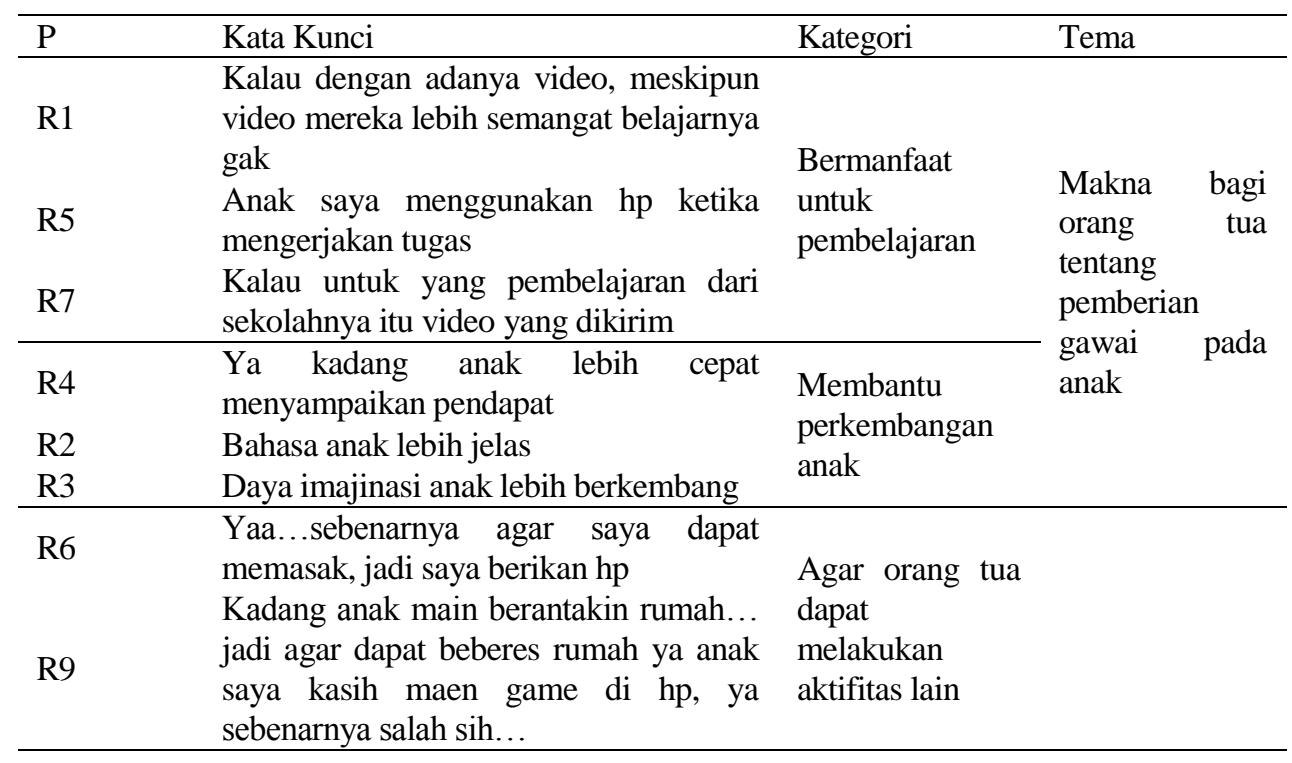

Semua partisipan orang tua dalam hal ini ibu menyampaikan tentang persepsi mereka tentang pemberian gawai pada anak terutama berkaitan dengan masa pandemik Covid-19 ini yang kegiatan pembelajaran pada guru PAUD menggunakan gawai sebagai media perentara pembelajaran. Hal ini terlihat pada kutipan wawancara berikut ini:

"Kalau untuk yang pembelajaran dari sekolahnya itu video yang dikirim sama umminya dilihatin, eh nanti pembelajarannya baru didampingin setelah videonya selesai ditonton. Jadi kalau enggak dilihatin juga sih sebenernya dia mau belajar, Cuma lebih tertarik lagi kalau dia melihat hasil yang dikirim sama umminya..." 
Selain deskripsi diatas orang tua juga mengatakan pemberian gawai bagi orang tua untuk membantu anak lebih pintar, membantu perkembangan anak. Hal ini terlihat dari pernyataan partisipan berikut:

"Umm.. anak saya itu saya lihat saat menggunakan gawai ada keterampilan baru yang didapat misalnya anak sudah bisa membaca doa pendek, dan kadang sudah bisa mencerita dengan bai kapa yang ditoton, artinya bagus ya...."

"Bagi kami saat sekarang ini agar proses pembelajaran dapat terus berlangsung ya kami sampaikan melalui gawai kepada anak melalui orang tua, artinya gawai ini membantu anak dapat belajar, dari video pembelajaran yang kami kirimkan, anak mengamati video itu, kemudian meniru dan mencoba, misalnya kami kirimkan video doa makan, nah anak melihat video itu trus dipraktekan kepada orang tua...."

Selain bermanfaat untuk pembelajaran dan perkembangan anak, orang tua juga mengatakan makna memberikan gawai pada anak adalah agar tua dapat melakukan aktifitas lainnya. Menurut orang tua dengan anak usia prasekolah ini, anak sangat aktif di rumah, kadang orang tua ingin melakukan pekerjaan rumah tangga sedikit kesulitan karena anak selalu meminta untuk ditemani bermain. Informasi ini peneliti peroleh dari partisipan dengan anak pertama usia prasekolah. Hal ini dapat dilihat pada kutipan berikut:

"Yaa...sebenarnya agar saya dapat memasak, jadi saya berikan hp. Saya kan baru punya anak satu perempuan usia 4 tahun, anak juga BDR nah lebih banyak bermain... kadang saya yang menemani,

\section{Konten yang Dibuka oleh Anak pada Gawai}

Tabel. 4

Analisis Tematik Konten yang Dibuka Anak

\begin{tabular}{llll}
\hline P & Kata Kunci & Kategori & Sub Tema \\
\hline R4 & $\begin{array}{l}\text { Kadang anak saya buka K-Pop, itu tidak } \\
\text { sesuai ajaran agama dan Batasan umur }\end{array}$ & $\begin{array}{l}\text { Konten kurang } \\
\text { baik buat anak }\end{array}$ & $\begin{array}{l}\text { Konten } \\
\text { dibukan yang } \\
\text { anak pada gawai } \\
\text { R4 }\end{array}$ \\
\cline { 1 - 2 } negative dari gambar, pakaian, dan kata- \\
kata & $\begin{array}{l}\text { Konten positif biasanya kayak nyanyi, } \\
\text { atau game boneka, yang bisa membuat } \\
\text { anak berpikir }\end{array}$ & $\begin{array}{l}\text { Konten Positif } \\
\text { untuk } \\
\text { perkembangan } \\
\text { anak }\end{array}$ & \\
\hline R8 & $\begin{array}{l}\text { Anak menonton video tentang islami,itu } \\
\text { baik menurut saya }\end{array}$ & & \\
\hline
\end{tabular}

Deskripsi konten yang dibuka anak dalam gawai menjelaskan ada 2 kategori yang dihasilkan yaitu konten kurang baik buat anak dan konten positif untuk perkembangan anak. Hal ini dapat terlihat pada kutipan berikut ini:

"yang kadang tidak terkontrol oleh orang tua, kita seirng melihat anak-anak yang berkumpul sering memakai hp bukan untuk belajar, (partisipan $R 2$ baris 154-157).

"Konten negatif itu game online termasuk negatif. Anak kadang kita tidak awasi beliau membuka itu” (Partisipan Rl baris 98-100)

Berdasarkan hasil wawancara dengan partisipan guru, mereka mengatakan bahwa perlu pengawasan orang tua juga dalam pembalajaran daring ini karena kadang anak setelah membuka video belajar saat itu juga anak membukan video lain di youtube. Peran orang tua 
sangat diperlukan dalam mengawasi dan mendapingi anak saat menggunakan gawai. Pendapat ini digambarkan partisipan dalam kutipan wawancara berikut:

"tergantung orang tuanya juga, kan kalua seperti kita pembelajarannya ada yang seperti video dikirim ke grup kelas masing-masing. Nah orang tua kalau melihatkan videonya otomatis anak melihatkan, jadi bisa dikatakan menggunakan gawai juga, jadi perlu orang tua mendampingi agar anak tidak membuka video lainnya. (Partisipan R1 Guru, baris 123-130)

"buka video edukasi sepeti baca, huruf hijaiyah dll..(partisipa R5 baris 110)

\section{Durasi Penggunaan Gawai pada Anak Usia 4-6 Tahun}

Tabel. 5

Analisis Tematik Sub Tema Berbagi Informasi tentang Perawatan Anak

\begin{tabular}{|c|c|c|c|c|}
\hline $\mathrm{P}$ & Kata Kunci & Kategori & Sub Ter & \\
\hline R5 & $\begin{array}{l}\text { Maksimalnya } 3 \text { jam sehari dia boleh } \\
\text { maen hp }\end{array}$ & \multirow[t]{2}{*}{ Durasi waktu } & \multirow{4}{*}{$\begin{array}{l}\text { Durasi } \\
\text { gawai }\end{array}$} & \multirow{4}{*}{ penggunaan } \\
\hline $\mathrm{R} 2$ & Ada waktu tertentu, sekitar 5-10 menit & & & \\
\hline R6 & $\begin{array}{l}\text { Anak hanya boleh bermain gawai pada } \\
\text { hari sabtu, minggu atau hari libur }\end{array}$ & \multirow[t]{2}{*}{ Batasan Waktu } & & \\
\hline R9 & Memberikan gawai dari jam 7-10 & & & \\
\hline
\end{tabular}

Berdasarkan wawancara dengan partisipan, beberapa orang tua mengatakan lamanya waktu anak menggunakan waktu tidak menentu, kadang maksimal 3 jam sehari. Namun saat ada pembelajaran dari sekolah anak bisa menonton di gawai bisa lebih lama. Hal ini seperti diungkapkan oleh paritispan berikut:

"Maksimalnya 3 jam sehari dia boleh maen hp,aaa...itu kadang sekali duduk dan kadang di selingi beberapa jamnya."(P2 baris 87)

Partisipan lainya mengatakan pendapat yang berbeda, waktu anak bermain gawai sekitar 5-10 menit, setiap habis makan. "Kadang juga saya batasin waktunya. Tergantung aktifitas anak hari itu".

\section{Kontrol terhadap Penggunaan Gawai pada Anak}

Tabel. 6

Analisis Tematik Sub Tema Batasan dan Aturan Orang tua terhadap Penggunaan Gawai pada Anak

\begin{tabular}{|c|c|c|c|}
\hline $\mathrm{P}$ & Kata Kunci & Kategori & Sub Tema \\
\hline $\mathrm{R} 1$ & $\begin{array}{l}\text { Anak boleh beramin gawai setelah } \\
\text { membantu membereskan mainan }\end{array}$ & \multirow{2}{*}{ Aturan orang tua } & \multirow{5}{*}{$\begin{array}{l}\text { Kontrol } \\
\text { Orang tua } \\
\text { dalam } \\
\text { pemberian } \\
\text { Gawai }\end{array}$} \\
\hline R9 & $\begin{array}{l}\text { Anak di izinkan bermain gawai setelah } \\
\text { makan }\end{array}$ & & \\
\hline $\mathrm{R} 10$ & Diajak jalan-jalan & Kegiatan lain & \\
\hline R6 & Dikasih pengertian dulu & Memberi pengertian & \\
\hline $\mathrm{R} 3$ & Ada batasanya kita menggunakan gawai & Pembatasan & \\
\hline
\end{tabular}

Berdasarkan wawancara dengan partisipan, beberapa orang tua mengatakan melakukan pengotrolan dalam pemberian gawai, kategori yang dihasilakan ada 4 yaitu aturan orang tua,kegiatan lainnya, member pengertian, dan pembatasan. Hal ini seperti 
diungkapkan oleh paritispan berikut:

"Kalau untuk gawai. kemarin-kemarin ini ummi ngasihnya pakai syarat misalnya dia sudah menyelesaikan apa...dia mau ngerjai apa. (Partisipan Rl Baris 121-123)

\section{Dampak Gawai pada Perkembangan Anak}

Tabel. 7

Analisis Tematik Sub Tema Dampak Positif pada Perkembangan Anak

\begin{tabular}{|c|c|c|c|}
\hline $\mathrm{P}$ & Kata Kunci & Kategori & Sub Tema \\
\hline R4 & $\begin{array}{l}\text { Dia lebih mudah menyampaikan } \\
\text { sesuatu }\end{array}$ & \multirow{2}{*}{$\begin{array}{l}\text { Mengenal Warna } \\
\text { dan bahasa }\end{array}$} & \multirow{6}{*}{ Dampak positif } \\
\hline R2 & Membuat anak jadi kreatif & & \\
\hline R1 & Dia punya bakat ngedance & Fisik motorik & \\
\hline R9 & $\begin{array}{l}\text { Dimasa ini anak dapat berkomunikasi } \\
\text { dengan teman sekelasnya }\end{array}$ & $\begin{array}{l}\text { Menambah teman } \\
\text { sosialisasi }\end{array}$ & \\
\hline R1 & Dapat nilai agama dan moral & Nilai moral dan & \\
\hline R4 & Penanaman nilai moral & agama & \\
\hline
\end{tabular}

Berdasarkan wawancara dengan partisipan orang tua, mereka menjelaskan ada dampak positif dan negatif dengan memberikan anak gawai baik untuk pembelajaran maupun untuk anak bermain. Hal ini digambarkan partisipan berikut ini:

"Banyak tahu dunia luar karena pembelajaran banyak bukan hanya dari sekolah, bisa dari sosial media”"(partisipan R3 baris 79-83)

"Kalau dari dampak positif tergantung apa yang ditonton anak, missal upin ipin itu dapat nilai agama dan moral, dia bertanya do'a-do'a (partisipan RI bari 222-225)

Selain dampak positif dari penggunaan gawai penelitian ini juga menghasilkan ada dampak negatif bagi anak dalam penggunaan gawai. Menurut partisipan orang tua dampak negatif kepada kesehatan mata lebih dominan disampaikan orang tua. Selain itu juga dampak pada perilaku negatif anak seperti meniru kata-kata kasar pada konten yang dibuka anak pada gawai.

Tabel. 8

Analisis Tematik Sub Tema Dampak Negatif pada Perkembangan Anak

\begin{tabular}{|c|c|c|c|}
\hline $\mathrm{P}$ & Kata Kunci & Kategori & Sub Tema \\
\hline $\mathrm{R} 1$ & Kata-katanya itu agak negative kasar & \multirow{2}{*}{$\begin{array}{l}\text { Kata-kata negatif } \\
\text { dan kasar }\end{array}$} & \multirow{9}{*}{ Dampak Negatif } \\
\hline $\mathrm{R} 2$ & Kartun yang berupa kekerasan dicontoh & & \\
\hline $\mathrm{R} 1$ & Anak malas bergerak & Kurang & \\
\hline R3 & Anak hanya di rumah & Sosialisasi & \\
\hline $\mathrm{R} 2$ & Anak menangis & \multirow{2}{*}{ Anak Emosian } & \\
\hline $\mathrm{R} 2$ & Anak mudah marah & & \\
\hline $\mathrm{R} 1$ & Gangguan kesehatan mata & \multirow{3}{*}{$\begin{array}{l}\text { Masalah } \\
\text { kesehatan }\end{array}$} & \\
\hline $\mathrm{R} 2$ & Anak susah maka & & \\
\hline R4 & Kurang Tidur & & \\
\hline
\end{tabular}


Berdasarkan wawancara dengan partisipan orang tua sebagian besar partisipan mengatakan dampak yang dominan adalah pengaruh pada kesehatan mata, selain itu anak juga lupa waktu sehingga kadang lupa untuk makan dan melakukan aktifitas lain. Hal ini seperti di jelaskan oleh partisipan berikut:

“...atau nonton youtube yang tidak perlu ditonton. Mata nya juga, mungkin pedih kena radiasi. (Partisipan $R 2$ baris ke $87-88$ )

"kakak itu agak sensitif juga matanya, kalo capek dikit dia langsung gatal matanya. Jadi itu tadi, Cuma kalo gak dikasih kadang kasihan, nangis. Paling kayak gitu lahditegasinnya kalau udah ada yang sakit, kalau terlaludikasih terus takut efek yang tadi. Sejak corona kan belajar dirumah, nah dia lebih sering main hp." (Partisipan RI baris ke 196-201)

\section{PEMBAHASAN}

\section{Makna bagi Orang tua tentang Pemberian Gawai pada Anak}

Hasil penelitian ini menggambarkan makna orang tua dalam pemberian gawai itu bermanfaat untuk pembelajaran dam membantu dalam perkembangan anak. Partisipan pada penelitian ini sebagian besar mengatakan saat masa pandemi Covid-19 ini gawai sangat memiliki peran penting dalam proses pembelajaran. Penggunaan media gawai dalam proses belajar pasti memiliki nilai positf dan negatif bagi orang tua, tetapi orang tua selaku pendamping belajar mampu mengarahkan anak kepada sisi positif media tersebut untuk proses pembelajaran dan perkembangan anak karena merupakan usia emas bagi pertumbuhan dan perkembangan otak mereka diwaktu usia anak-anak (Nihayati et al., 2020).

Penelitin Aulia et al., (2019) menjelaskan bahwa penggunaan internet dalam pembelajaran memberikan alternatif untuk diterapkan pada pembelajaran pada saat ini untuk meningkatkan kemandirian belajar siswa. Hasil penelitian Harsismanto et al., (2021) menjelaskan bahwa ada pengaruh yang signifikan secara statistic intervensi finger painting terhadap peningkatan perkembangan motorik halus anak.

Penggunaan gawai dalam aktivitas belajar anak memberi pengaruh besar terhadap pembelajaran dan perkembangan mereka tergantung pada kontrol dan pengaruh dari orang tua. Internet bisa memberikan kemudahan untuk mendapat informasi bagi anak dalam mendukung kereatifitas belajarnya. Hasil penelitian ini sejalan dengan hasil penelitian yang dilakukan oleh Zaini \& Soenarto (2019) mengatakan bahwa smartpohone dan tablet yang digunakan pada anak usi dini mempuanyai nilai manfaat jika dikaitkan dengan media pembeljaran untuk pengembangan kemampuan anak. Hasil ini menyakatakan bahwa $78 \%$ orang tua perlunya aplikasi yang ada di smartpohone dan tablet yang bertujuan untuk mengasah perkembangan kompetensi anak.

\section{Konten yang Dibuka oleh Anak pada Gawai}

Hasil penelitian ini menggambarkan bahwa terdapat konten yang kurang baik buat anak seperti aplikasi facebook, you tube, tik-tok dan instagram sehingga anak-anak sangat menikmati keasikan dalam menggunakan gawai. Konten tersebut membuat anak asik sendiri oleh gawai nya dan menimbulkan dampak seperti mereka akan lupa akan kebutuhan pokok anak yaitu belajar dan bersosialisasi dengan benar di kehidupan.

Hasil penelitian ini juga sejalan dengan penilitian yang dilakukan oleh Indriyani et al., (2019) yang mengatakan bahwa gawai lebih memberikan dampak negatif dari pada positif karena banya konten yang tidak baik dapat dibuka oleh anak seperti film kartun, game, you tube, musik, sosial media dan sinetron atau FTV. 
Pengenalan gawai yang diberikan terlalu dini dan tidak terkontrol pada anak sangat berpengaruh pada kehidupan sosial anak. Anak pada usia ini sangat rentan dan mudah dipengaruhi oleh apa yang mereka lihat, denganr dan dilakukan oleh lingkungan maupun berbagai hal yang terdapat pada konten gawai. Anak yang telah menganal media soali, mencari informasi, game online dan lain-lain. Semuanya dapa mempengaruhi aspek kehidupan mereka (Rusmianto \& Putra, 2020).

\section{Durasi Penggunaan Gawai pada Anak Usia 4-6 Tahun}

Hasil penelitian ini mengatakan bahwa orang tua telah membatasi penggunaan gawai itu maksimal 3 jam sehari. Namun saat ada pembelajaran dari sekolah anak bisa menonton dengan gawai bisa lebih lama. Dari pembatasan atau durasi waktu dalam penggunaan gawai yang dilakukan orang tua akan memberikan banyak waktu untuk anak belajar dirumah yang memberikan kesempatan mengulang pembelajaran yang dilakukan di sekolah. Penelitian yang dilakukan Syifa et al., (2019) menyebutkan bahawa $26 \%$ anak mengunakan gadget lebih dari 2 jam sehari, dan seb $42 \%$ pemakaian gawai kurang dari 1 jam. Hasil penelitian tersebut juga menjelaskan bahwa sebagai besar orang setuju anak hanya mengunakan gawai 1 jam dalam sehari.

\section{Kontrol terhadap Penggunaan Gawai pada Anak}

Hasil penelitian ini mengatakan bahwa beberapa orang tua melakukan pengontrolan dalam pemberian gawai seperti orang tua dalam penggunaan, kegiatan lain kecuali pembelajaran, memberikan pengertian penggunaan gawai dan pembatasan waktu. Hasil penelitian ini sejalan dengan penelitian yang dilakukan oleh Widiastiti \& Agustika (2020) yang mengatakan bahwa dalam menggunakan media elektronik anak sering memilih permainan dan terlalu ekstream, sehingga orang tua perlu melarang anak nya memiliki gawai dan juga menerapkan aturan dalam penggunaan teknologi seperti melarang anaknya memiliki telepon seluler (ponsel) sebelum berusia 14 tahun, membatasi waktu dengan komputer dengan cara ini keluarga mereka memiliki waktu yang lebih banyak untuk berkumpul bersama keluarga, Tidak mengijinkan anggota keluarga membawa ponsel ketika waktu makan, menentukan waktu dan jumlah jam setiap hari untuk menonton televisi dan menggunakan ponsel sehingga anak-anak bisa pergi tidur lebih awal dibanding anak lain.

Orang tua hendak hendaknya tegas mendidik jika anak terlalu lama terpapar gawai. Kontrol orang tua dalam penggunaan gawai terutama pada anak usia prasekolah sangat penting, Karena tanpa pengawasan orang tua anak akan melihat kontek yang tidak baik untuk kesehatan psikologisnya (Kusumawardhani et al., 2019).

\section{Dampak Gawai pada Perkembangan Anak}

Hasil penelitian ini mengatakan bahwa gawai memiliki dampak positif dan negatif terhadap anak seperti dalam pembelajaran dan bermain untuk anak. Gawai sebagai sarana belajar tidak hanya memberi kontribusi pada pencapaian kognitif, namun juga terhadap kemampuan berbahasa mereka. Anak usia prasekolah hingga usia SD kelas bawah berada dalam fase perkembangan bahasa secara ekspresif, yang artinya anak bisa mengungkapkan keinginan, pendapat, dan penolakannya melalui bahasa lisan. Bahasa dan bicara anak merupakan potensi yang berkembang cepat sehingga menjadi pola kebiasaan dimana perkembangan anak pada usia dini mempengaruhi penyesuaian pribadi serta sosialnya, dengan bertambahnya usia anak maka potensi itu akan terbentuk. 
Selain dampak positif terhadap perkembangan bahasa anak. Gawai juga memberikan dapak negatif terutama pada aspek sosial anak. Anak cenderung hanya fokus pada gawai dan malas untuk melakukan aktifitas fisik. Hal ini menyebabkan anak tidak melakukan kegiatan sosialisasi, yang mempengaruhi nilai sosial anak (Syifa et al., 2019). Hasil penelitian ini sejalan dengan Subarkah (2019) yang mengatakan bahwa gawai memiliki dampak negatif terhadap anak. Dampak yang di timbulkan akibat penggunaan gawai yaitu anak bisa terkena pengaruh buruk dari internet termasuk rentan menjadi korban predator, atau bullying (kekerasan) di dunia maya, perkembangan otak anak dapat terpengaruh, Perkembangan fisiknya dapat terhambat karena anak menjadi malas bergerak, perkembangan kesehatan mental dan sosialnya dapat terganggu karena biasanya anak yang kecanduan internet dan gawai tidak mampu bersosialisasi dengan baik, kemungkinan anak tidak bisa mandiri dalam menyelesaikan masalah akibat ketergantungannya pada gawai dan kemampuan berpikirnya menjadi lamban terutama saat menghadapi masalah dalam situasi nyata.

Dari hasil penelitian yang diperoleh oleh peneliti partisipan orang tua menyatakan bahwa anak lebih cenderung hanya tidur-tiduran sambil menonton hp dan bermain game. Malas mengerjakan rutinitas sehari-hari, bahkan untuk makanpun harus disuap, karena sedang asyik menggunakan gawainya. Perlu mendapat perhatian orang tua jika mereka sudah apatis pada lingkungan seperti tidak menoleh kiri dan kanan atau mempedulikan orang disekitarnya. Bahkan tidak menyapa orang yang lebih tua.

Gawai sangat berpengaruh terhadap perilaku anak. Anak yang aktif dalam gawai akan lebih pasif dalam interaksinya dengan lingkungan sekitar karena pada realitanya ketika anak telah fokus terhadap suatu hal yang disukai dalam hal ini gawai maka anak cenderung mengabaikan segala hal, jika tidak dilakukan kontrol oleh orang tua hal ini dapat berakibat fatal bagi anak-anak.

\section{SIMPULAN}

Penggunaan gawai pada anak memiliki dampak positif dan negatif pada perkembangan anak. Dampak positif pada perkembangan anak yaitu pada perkembangan bahasa, membantu anak mengembangkan kreatifitas, meningkatkan nilai agama dan moral. Namun dapat negatif lebih dominan daripada positif yaitu gangguan kesehatan mata, anak cenderung apatis, gangguan fungsi sosialisasi anak dan gangguan emosi pada anak. Hasil penelitian ini terdapat beberapa tema yang memerlukan kajian lebih mendalam terutama pada pengaruh konten gawai tertentu pada aspek perkembangan anak.

\section{SARAN}

Diharapkan orang tua agar memberikan pengawasan yang tepat terhadap anak dalam penggunaan gadget.

\section{DAFTAR PUSTAKA}

Aulia, L. N., Susilo, S., \& Subali, B. (2019). Upaya Peningkatan Kemandirian Belajar Siswa dengan Model Problem- Based Learning Berbantuan Media Edmodo. Jurnal Inovasi Pendidikan IPA, 5(1), 69-78. DOI: 10.21831/jipi.v5i1.18707

Chusna, P. A. (2017). Pengaruh Media Gadget pada Perkembangan Karakter Anak. Dinamika Penelitian: Media Komunikasi Sosial Keagamaan, 17(2), 315-330. https://doi.org/10.21274/dinamika/2017.17.2.315-330 
Harsismanto, J., Fredrika, L., Padila, P., \& Andri, J. (2020). Pengaruh Intervensi Finger Painting terhadap Peningkatan Perkembangan Motorik Halus Anak Prasekolah. Prosiding Senantias, 1(1), 473-482. http://www.openjournal.unpam.ac.id/index.php/Senan/article/view/8942/5691

Indriyani, M., Sofia, A., \& Anggraini, G. F. (2019). Persepsi Orang Tua terhadap Penggunaan Gadget pada Anak Usia Dini. Indonesian Journal Of Early Childhood, 45(15), 37. http://jurnal.fkip.unila.ac.id/index.php/IJECI/article/view/16887

Kusumawardhani, A., Segara, A. A., \& Supriadi, W. (2019). Peran Orang Tua Dalam Pengawasan Penggunaan Internet Pada Anak. Abdikarya, 3(3), 1-4. http://jurnal.untag-sby.ac.id/index.php/abdikarya/article/download/3731/2831

Maria, I., \& Novianti, R. (2020). Efek Penggunaan Gadget pada Masa Pandemi Covid-19 terhadap Perilaku Anak. Atfäluna: Journal of Islamic Early Childhood Education, 3(2), 74-81 https://journal.iainlangsa.ac.id/index.php/atfaluna/index

Nihayati, N., Kayyis, R., \& Khasanah, B. A. (2020). Menciptakan Pembelajaran Menyenangkan di Rumah Pada Era Pandemi Covid-19. Bagimu Negeri : Jurnal Pengabdian Masyarakat, 4(1), 1-8

Rusmianto, A., \& Putra, K. P. (2020). Studi Pengetahuan Orang Tua tentang Gawai dan Pemberian Gawai pada Anak Usia 9-12 Tahun. Jurnal Keperawatan Muhammadiyah, 5(1), 2020. http://journal.um-surabaya.ac.id/index.php/JKM

Setianingsih, S. (2018). Dampak Penggunaan Gadget pada Anak Usia Prasekolah Dapat Meningkatkan Resiko Gangguan Pemusatan Perhatian dan Hiperaktivitas. Gaster, 16(2), 191. https://doi.org/10.30787/gaster.v16i2.297

Subarkah, M. A. (2019). Pengaruh Gadget terhadap Perkembangan Anak. Rausyan Fikr, 15(1), 125-139. DOI: 10.31000/rf.v15i1.1374

Syifa, L., Setianingsih, E. S., \& Sulianto, J. (2019). Dampak Penggunaan Gadget terhadap Perkembangan Psikologi pada Anak Sekolah Dasar. Jurnal Ilmiah Sekolah Dasar, 3(4), 538. https://doi.org/10.23887/jisd.v3i4.22310

Utami, A. N. (2019). Dampak Negatif Adiksi Penggunaan Smartphone terhadap AspekAspek Akademik Persona Remaja. Perspektif Ilmu Pendidikan, 33(1), 1-14. https://doi.org/10.21009/pip.331.1

Wardhani, F. P. (2018). Student Gadget Addiction Behavior in the Perspective of Respectful Framework. $\quad$ Konselor, $\quad 7(3), \quad 116-123$. https://doi.org/10.24036/0201872100184-0-00

Widiastiti, N. L. G. M., \& Agustika, G. N. S. (2020). Intensitas Penggunaan Gadget oleh Anak Usia Dini. Jurnal Pendidikan Anak Usia Dini, 8(2), 112-120. https://ejournal.undiksha.ac.id/index.php/JJPAUD/article/download/25179/15709

Zaini, M., \& Soenarto, S. (2019). Persepsi Orang tua terhadap Hadirnya Era Teknologi Digital di Kalangan Anak Usia Dini. Jurnal Obses: Jurnal Pendidikan Anak Usia Dini, 3(1), 254-264. https://doi.org/10.31004/obsesi.v3i1.127 